\section{Neuropathy due to Amyloid in Myelomatosis}

\section{G. A. B. DAVIES-JONES, MARGARET M. ESIRI}

British Medical fournal, 1971, 2, 444

In 1958 Victor, Banker, and Adams described five cases of peripheral neuropathy complicating myelomatosis. They wrote: "the idea that amyloidosis is responsible for myelomatous neuropathy though theoretically entertaining lacks pathological confirmation." The following report is on an elderly man with myelomatosis and peripheral neuropathy in whom amyloid infiltration of the peripheral nerves was found.

\section{Case Report}

A 72-year-old man developed postinfluenzal staphylococca pneumonia in November 1967. This responded to penicillin, but between March and October 1968 he had recurrent attacks of a pneumonic-like illness. He was admitted to another hospital in October 1968 because of a brief episode of unconsciousness followed by transient right hemiparesis. The only abnormality found on examination was a right nuclear facial palsy. Laboratory findings were: haemoglobin $80 \%$; W.B.C. 4,600; E.S.R. $122 \mathrm{~mm} / \mathrm{min}$ serum albumin $2.6 \mathrm{~g}$, globulin $5.6 \mathrm{~g} / 100 \mathrm{ml}$; intense narrow band of gammaglobulin on serum eletrophoresis; $10 \%$ plasma cells in bone marrow specimen; absence of Bence Jones proteose; normal C.S.F. He was thought to have myelomatosis. Because he developed lumbar/sacroiliac pain and progressive anaemia he was transfused and started on cyclophosphamide $50 \mathrm{mg}$ twice daily.

In January 1969 he was transferred for the investigation of progressive weakness of the legs. On examination he was an ill-looking anaemic man. The cardiovascular system and abdomen were normal. There were scattered bilateral rales and rhonchi but otherwise the chest was normal. There was tenderness of the lumbar spine.

The relevant findings in the nervous system were a right nuclear seventh cranial nerve palsy; depressed superficial sensation on the hands extending up to the wrists, but normal proprioception, vibration, muscle tone, power, and reflexes; and flaccid paraparesis, with absent reflexes and flexor plantar responses, but impairment of superficial sensation and vibration in a stocking distribution up to the knees, with absent proprioception in the toes. Investigations were: haemoglobin $73 \%$; W.B.C. 3,400 (normal differential); platelet count 182,000; E.S.R. $111 \mathrm{~mm} / \mathrm{hr}$; urine analysis, $1,900 \mathrm{mg}$ of protein $/ 100 \mathrm{ml}$, with granular hyaline and cellular casts; blood urea $75 \mathrm{mg} / 100 \mathrm{ml}$; plasma sodium $129 \mathrm{mEg} / 1$; total serum protein $6.7 \mathrm{~g}$ (globulin $4.4 \mathrm{~g}$ )/100 ml; serum electrophoresis, pro-

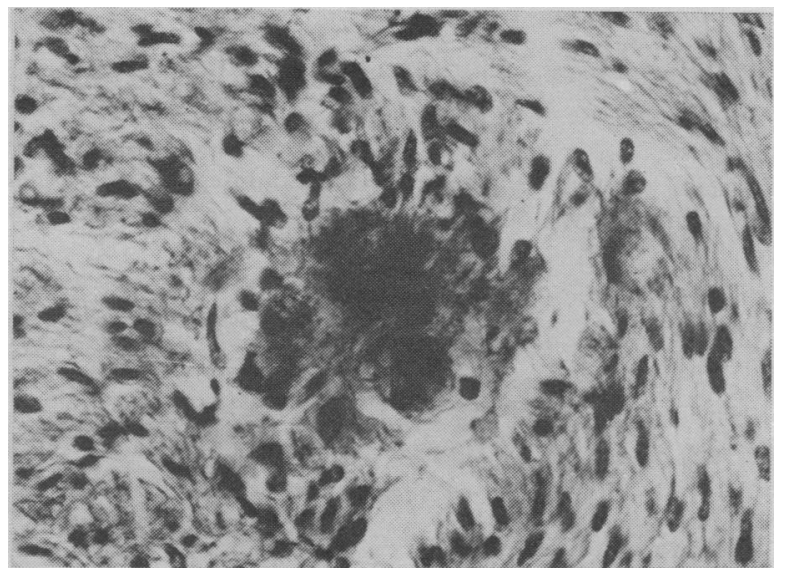

PIG. 1-Femoral nerve. Endoneurium with amyloid deposit at centre. Schwann cell nuclei darkly stained. (Congo red. x 192).

Radclifie Infirmary, Oxford

G. A. B. DAVIES-JONES, M.D., M.R.C.P., Senior Registrar in Neurology MARGARET M. ESIRI, B.M., B.CH., Research Officer in Neuropathology

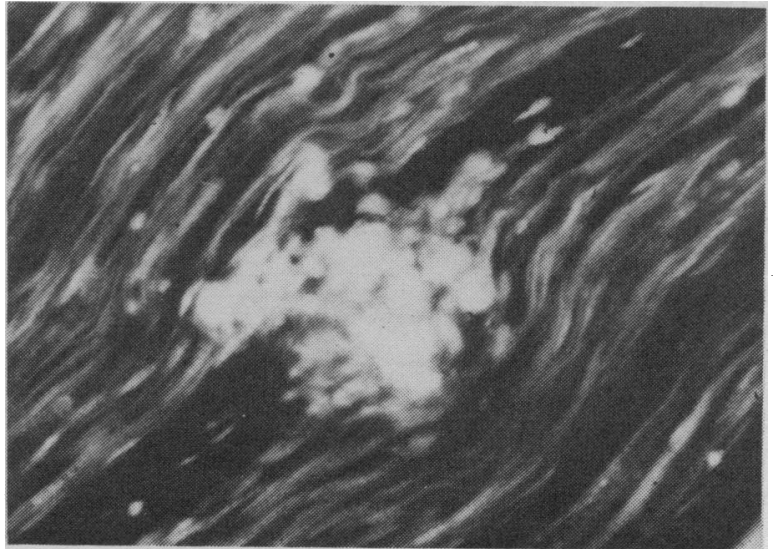

FIG. 2-Median nerve containing amyloid deposit. (Thioflavine T. Photographed under ultraviolet light. $x$ 120.)

nounced monoclonal band in the gammaglobulin fraction; serum immunoelectrophoresis IgG 4,050 mg, IgA $10 \mathrm{mg}, \operatorname{IgM} 10 \mathrm{mg} / 100$ $\mathrm{ml}$ (respective normal values 800 to $1,680 \mathrm{mg}, 140$ to $420 \mathrm{mg}, 50$ to $190 \mathrm{mg} / 100 \mathrm{ml}$ ). Blood culture grew Streptococcus pneumonia. During the eight days in hospital the bronchopneumonia progressed and he died of fulminating pneumococcal septicaemia.

Pathological Findings.-At necropsy there was severe bilateral bronchopneumonia, and the heart showed left ventricular hypertrophy with amyloid deposits in the walls of small coronary vessels. Amyloid was also present in the spleen, kidneys, pancreas, and adrenal glands. Myeloma deposits were found in the shaft of the femur. In the central nervous system the only abnormality was chromatolysis of anterior horn cells in the spinal cord. In all the peripheral nerves studied and in the dorsal root ganglia and nerve roots amyloid deposits were found lying interstitially and in the walls of the vasa nervorum (Figs. 1 and 2). There was widespread demyelination, with a lesser degree of axonal degeneration. muscle showed evidence of denervation atrophy. Electron microscopic examination of a portion of nerve showed deposits of fibrillar material having the ultrastructural characteristics of amyloid.

\section{Comment}

Snapper, Turner, and Moscovitz (1963) and Victor et al. (1958) showed peripheral neuropathy in myelomatosis secondary to axonal degeneration and segmental demyelination without infiltration by myeloma or amyloid tissue. Morley and Schweiger (1967) confirmed this and emphasized the association of the rare osteosclerotic form of myeloma with such neuropathy. Peripheral neuropathy due to amyloid accumulation in the vasa nervorum in a case of myelomatosis was documented by Campbell and Halford (1964). In none of Hesselvik's (1969) cases was amyloid found in the peripheral nerves.

The neuropathy of myelomatosis is usually due to segmental demyelination and axonal degeneration, and seldom due to direct infiltration of the peripheral nerves or nerve roots with myeloma tissue or amyloid accumulation of the vasa nervorum. This present case is the only one known to us where direct infiltration of the nerve itself by amyloid deposits was shown pathologically to be responsible for the neuropathy.

We are grateful to Dr. J. M. K. Spalding for permission to report this case, and to $\mathrm{Dr}$. J. T. Hughes for much assistance in defining the pathology.

\section{References}

Campbell, A. M. G., and Halford, M. E. H. (1964). British Medical fournal, 2, 1509 .

Hesselvik, M. (1969). Acta Neurologica Scandinavica, 45, 95.

Morley, J. B., and Schweiger, A. G. (1967). fournal of Neurology, Neurosurgery and Psychiatry, 30, 432.

Snapper, I., Turner, L. B., and Moscovitz, H. L. (1953). Multiple Myeloma, p. 33. New York, Grune and Stratton.

Victor, M., Banket, B. Q., and Adams, R. D. (1958). Fournal of Neurology, Neurosurgery and Psychiatry, 21, 73. 